\title{
Quality of Leadership and Implicated Constructs
}

\author{
Victor Manuel Monteiro Seco ${ }^{1}$, Pedro Miguel Castanheira Teixeira² \\ ${ }^{1}$ CAPP, Universidade de Lisboa, Lisboa, Portugal \\ ${ }^{2}$ Polytechnic Institute of Bragança, Bragança, Portugal \\ Email: victor.seco@gmail.com, pedro.teixeira@ipb.pt
}

How to cite this paper: Seco, V. M. M., \& Teixeira, P. M. C. (2019). Victor Manuel Monteiro Seco, Pedro Miguel Castanheira Teixeira. Open Journal of Leadership, 8, 95-113.

https://doi.org/10.4236/ojl.2019.83006

Received: May 25, 2019

Accepted: August 31, 2019

Published: September 3, 2019

Copyright (c) 2019 by author(s) and Scientific Research Publishing Inc. This work is licensed under the Creative Commons Attribution International License (CC BY 4.0).

http://creativecommons.org/licenses/by/4.0/

(c) (i) Open Access

\begin{abstract}
Purpose: The authors examine the role of values, trust, organizational culture, learning organizations and authentic leadership in explaining the quality of leadership. Design/Methodology: This is a theoretical text that allows approaches and intersections of the constructs with implications for the quality of leadership. Contributions/Findings: This present literature review confirms that there is a significant connection between authentic leadership and its components according to different authors' point of view. Research Limitations/Implications: It is necessary to consider further some other important authors' positions that are not considered in the present review. It was made a focused author's selection of different continents and realities. Originality/Value: This review contributes to enhance the compilation of existing research on the examination of authentic leadership and its most important components.
\end{abstract}

\section{Keywords}

Leadership, Authentic Leadership, Values, Trust and Learning Organizations

\section{Introduction}

Organizations are part of our life, they are the results of our personal commitment and, like us, are constantly evolving. But most of all, it is in the crucible of interpersonal relationships which this process develops.

Since the 30s of the last century that concern about the influence of the individual behavior on the attitudes of other members of a team it is cause for reflection. The development of more and best leaders is very important and citizens must strengthen and support good leaders and observe, through them, those who exploit them (Gardner, 1995). 
In recent years, ethical and moral crisis that have spread around the world, including scandals in various organizations of global reach, led the objective conditions to emergence of a leadership theory, authentic leadership, focused on principles, values and trust (Avolio \& Gardner, 2005; Cooper, Scandura, \& Schriesheim, 2005). This construct, which is embodied in complicity and complementarity concepts, it is a field of study with great potential at the micro and meso levels of Organizational Behavior. In fact, the values seminal character generates a sea of trust waves that feed organizational learning of the constituents, contributing to the configuration of an organizational culture strengthened by a genuine, sincere and positive leadership.

In a worldwide phase-change of principles and values, the quality of interactions between people on organizational structures, namely by the trust as value and attitude, and calling as work orientation, can be an element improving the functioning of the global society. Then, the importance of values gives the organizational culture a complex and crucial role in identifying and affective commitment of employees with the work communities to which they belong.

On the other hand, being aware that these organizations are subject to a vital imperative of change to meet the challenges that anticipate being faced in the future, we believe that it is appropriate to consider the concept of learning organizations. In its explanation, we have to consider the five disciplines-which Senge (2006) proposes as a construction base of learning organizations. The sensitivity of learning organizations that mark the difference among those are able to learn to continuously learn and those which learn looking to the past, not forgetting that those organizations only learn if their constituents continue learning.

The significance of the present research is linked to the social need for authenticity on labor relations. Leaders are not managers. More than that is the quality of leadership resulting from the positive psychological capacities of the leader and the positive ethical climate created. Satisfied followers produce a major value for society.

From the academic point of view, this research is fundamental in order to join, for the first time, leadership components so apart as organizational trust or the learning organizations. In fact, trust can be a transformation instrument of the future, spreading optimism and positivity. In the other way, learning organizations imply change propensity and continuous experiences that would be great if they are, in the next future, transformed into positive knowledge.

\section{Personal, Cultural and Organizational Values}

"Leaders are defined by their values and their character. The values of the authentic leader are shaped by personal beliefs, developed through study, introspection, and consultation with others-and a lifetime of experience" (George: Authentic Leadership, 2003).

We are not a leader when we want or why it happens. As stated, Stephen \& Covey, leadership is an expression defined by the behavior and the "voice" of 
each other and with those who will make way together. The author considers that there are innate goods that run through the DNA of our personality: the freedom and the power to choose on the one hand, and on the other, the principles, universal, immutable and farsighted. The four natural parts of our "voice", body, heart, mind and spirit, form a synergistic whole that expresses the needs we feel, the passions we live, the talents we feed and the awareness of what we intuit and we do.

Thus, it makes sense to refine and fine-tune the "voice" analyzing its parts through the intelligence enclosure associated with each. The body of intelligence that allows us to use matter and often commits excesses. The intelligence of the heart, which makes us thrill and relate with whom we establish communication. The reasoning intelligence, which differentiates our knowledge and leads preferably to academic and social certification. Finally, the smart sensibility that distinguishes us from higher mammals and from the rest other animals. That which is closely linked to the need, felt by human beings, to look for a meaning to the way it moves through. The meaning associated with waking up every day and have the privilege of looking at the sun, despite all the attacks on the ecological balance as a result of free will of many, and feel desire to continue living. To this meaning we can still associate the vision and values that sustain it, emphasizing the things we believe in and the role of beliefs and values in our actions. This is what makes us human.

We need to live, love, learn and, above all, leave a legacy. A legacy of passage through life, our own and that of others. Because this, and beyond, we need, in our work, that boss pays us precisely, in the affective level we need people to love us deeply and gently, the rational plan chief fits us with creativity, so that in the spiritual realm we can serve others according to the fundamentals the universe.

Covey (2004) argues that we should conduct our lives in a balanced, integrated and powerful way. How? Disciplining the body, which Valverde (2000: p. 273) considered "is an ephemeral gift to an alien resident," living intensely passions with the heart, with the vision of what we want to happen without hurting anybody and always acting consciously. In this context, it is worth remembering one phrase of Teilhard de Chardin, the French Jesuit philosopher: "We are not human beings having a spiritual experience, but spiritual beings having human experiences."

In another dimension of analysis, a person, the human being is linked to the organization where he works in a complex and multidimensional way. Tamayo (2005), seconded by Rego, Souto, \& Cunha (2007), like Meyer \& Allen (1991), considered the organizational commitment in its multiple components: normative, instrumental and emotional.

Not forgetting the influence of others, let us focus on the affective component of organizational commitment as the feeling of belonging and closeness employee has for the organization. To Tamayo (2005: p. 195), the "affective commitment is more than the simply passive loyalty to an organization". 
As well argues Rego, "in their capacity as social and gregarious beings by nature, people psychological well-being depends to a large extent on the ability to satisfy identity and belonging needs "being organizations a" physical, psychological and social space open to the possibility of satisfying such needs."

Tamayo (2005: pp. 195-196) states predictors of organizational commitment among which highlights the organizational variables, "cultural forms to do the job in certain organizations." For the author, values, standards and organizational policies affect the development of work and, a fortiori, employees' commitment.

Values represent basic convictions that "a specific mode of conduct or condition of existence is individually or socially preferable to the contrary or opposite mode of conduct or existence" (Robbins, 2007).

Deeply, values are cognitive representations of needs and purposes. A full motivational sequence understands the needs at the source, represented by values that cognitively, in turn, mediate goals and intentions. The latter are behavioral antecedents, which is followed by some kind of reward that gives satisfaction (Locke, 1991). The role of values in the motivational process is fundamental, because they give meaning to the cognitive and cultural needs, turning them into goals and intentions.

Schwartz \& Bilsky (1987) also put the source of values on the demands or universal human needs. That is, they considered values as motivational goals, which express targets that each one wants to achieve in their life.

We can express the motivational values interaction distributing them in a circumflex reference, "two-dimensional circular structure" (Schwartz, 1992: p. 45), detailed in buds or colored pie (Figure 1). It aims to show the organization of motivational values given their similarities or differences depending on the color and its position (remoteness, proximity, opposition or contiguity).

The five motivational types that express individual goals and interests (selfdetermination, stimulation, hedonism, achievement and power) play in the multidimensional space, as opposed to those contiguous areas reserved for motivational types that express primarily goals and collective interests (benevolence, tradition and conformity). Motivational security and universalism types consisting of goals and interests of both individual and collective, are opposite and are located on the borders of these two areas.

This approach offers a very varied motivational range, with targets relating to virtually all the most significant aspects of everyday life and labor activity. It is a very useful feature for understanding and anticipating the behavior, which allows a very much differentiated assessment through ten motivations, each with specific goals (Schwartz, 1992, 1994, 2001).

Moreover, motivations have a dynamic organization determined by the nature of the target interests that simplifies the anticipation of motivational behavior from the structure of the person. For example, people who have strong hedonistic motivations are generally less prone to control personal impulses that clash of group norms (Schwartz, 1992, 1994, 2001). 


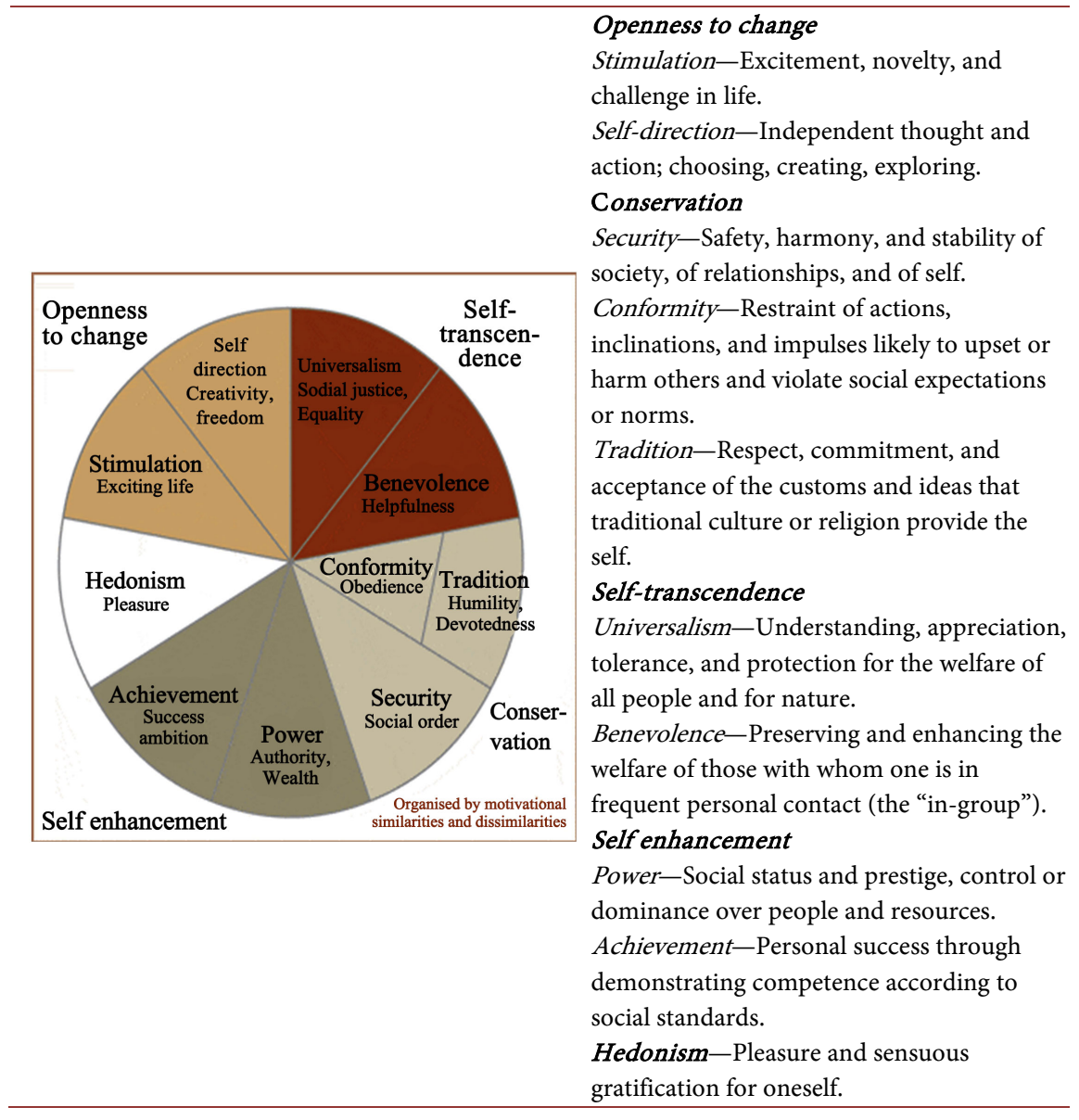

Figure 1. Multi-dimensional model of the ten types of motivational values (Available 7th July 2015 http://essedunet.nsd.uib.no/cms/topics/1/1/1.html).

Shalom Schwartz's investigations, about personal and cultural values in different environments, were instrumental in developing strong references in the study of values in general and organizational values in particular.

Initially, the work of this Israeli author pointed to the importance of the values cultural dimension. Schwartz thought that cultural values allowed better understand the meaning of work in people lives, in that to be a result of superstructural decision processes reduced the influence of the priorities combined with the personal values (Schwartz, 1999: p. 24, 42).

Schwartz developed and verified empirically, through a cross-cultural survey conducted in over 60 countries, a motivational structure model of personal values. These surveys have been postulated several reasons that were identified through the priorities given by the people to values. What is the relationship of values to the individual motivations?

This theory proposes us two types of applications: on the one hand, the results "can be utilized to predict and understand national differences on work-related issues. Research may proceed in two directions. In order to explain observed differences among nations in the organization of work, in work ideologies, or in work practices, for example, these differences may be connected to national dif- 
ferences on one or more of the cultural value types" (Ibidem, p. 38); on the other, given the differences detected we can reflect on "the types of work goals whose pursuit is encouraged and rewarded, rather than discouraged and sanctioned, depend in part on the prevailing cultural value emphases in a society" (Ibidem, p. 43).

Now transposing our focus to the issue of organizational values, it becomes important because, in the analysis of many authors, they are compelling elements in the deep understanding of organizations.

To Hofstede (1997: pp. 211-212), the practices (including symbols, heroes and rituals) and values are, quintessential, the two of any organization's culture elements. This author considers such weight values in organizations which assert that people in different organizations show considerable differences in practices, but much smaller differences in values.

Tamayo (1996: p. 62) raises the question of organizational values linked to the practice and argues that "almost every employee is able to detect differences in the values that dominate in certain organizations and determining its climate and its organizational culture". This author defines organizational values "as principles or beliefs, hierarchically organized, relating to types of structure or desirable models of behavior that guide the company's life and are at the service of individual, collective or mixed interests" (o.c., p. 63) expressing "a fundamental dimension of organizational culture as it is experienced by its members" (o.c., p. 64). The fact is that this belief constitutes a cognitive appropriation of responding ways to problems encountered in the organization. Beliefs only become values if they have positive results in practice. It will be this success that will serve as individual and collective motivation.

Thus, Tamayo \& Gondim (1996: p. 63) highlight various aspects in defining organizational values: the cognitive and motivational aspects, the role and the hierarchical organization of values. The cognitive aspect is related to beliefs, "ways of knowing the organizational reality, and ready and privileged answers to organizational problems ... valued, emphasized in organizational life." As the motivational aspect, the authors consider that it is in the "heart of organizational values ... they express interests and one's desires".

The authors point out, too, the guiding light of values concerning the life of the company and the behavior of its members and the judge function of behavior that is "relevant to the organizational system" (ibid).

Another function of values is "... create similar mental models for operation and mission of the organization" so that the perceptions about the company, organizational behavior and tasks tend to be similar (ibid, p. 64). Thus, the organizational values will respect the rule of "distinction between what has value and what doesn't" (ibidem) and involve preferably will predicate their hierarchy.

Tamayo \& Gondim (1996) have advanced in their research with the empirical strategy of building an Organizational Values Scale, whose purpose was the assessment of organizational values starting from professionals' perceptions. To 
this end they undertook a survey of suggestions values along of public organizations elements. Then selected a representative sample of organizational values and tested in near a larger number of employees.

Given the results, based on three fundamental problems that any organization faces (the individual-group relationship, the need to develop a structure and a relationship of the organization with the natural and social environment) and the cultural approach to Schwartz values, proceeded to the construction of IVO (Inventory of Organizational Values) (Tamayo et al., 2000: p. 299).

Organizational values, like the personal and cultural values, "are principles that drive and guide the people and groups lives" so that the better we know the values of the organization, the easier it "predict the operation thereof and organizational behavior of its members" (Tamayo, 2005: p. 199).

Leaders can get the best of people, to make healthier their organizations, if they give greater importance to the balance between personal values and organizational values.

We do not resist register here an Arab thought:

"He who has health has hope. Who hopes can aspire to everything!"

\section{Authentic Leadership}

"Leadership is an observable, learnable set of practices. Leadership is not something mystical and ethereal that cannot be understood by ordinary people. Given the opportunity for feedback and practice, those with the desire and persistence to lead-to make a difference-can substantially improve their abilities to do so" (Kouzes \& Posner, 2012).

From the evidence of the bankruptcy of several US reference companies (Enron, WorldCom) and lack of honesty detected on the part of leaders (Awolowo, Garrow, Clark, Chan, \& Dora, 2018), emerged a new focus of interest in leadership that drive both researchers and professionals in the management and which went to be known as "Authentic Leadership" (AL).

From the Bill George perspective, a renowned management professional and also university professor, authentic leaders act according to five dimensions: understanding their purpose, practicing their strong values, leading with the heart, establishing close relations with the followers and demonstrating self-discipline (George, 2003: p. 36). In his 2007 book, “True North, Discovering your authentic Leadership", George used a very effective metaphor to present the importance of authenticity as he sees it: Top executives must use their internal compass to find, and then true north in the business world. The author believes that the leader brings people together around a purpose and common values beyond to empower followers to take over and lead authentically (Covelli \& Mason, 2017).

In the approach of university researchers, stand out Luthans and Avolio (2003 p. 243) that helped to improve the AL construct and defined it "as process that draws from both positive psychological capacities and a highly developed orga- 
nizational context, which results in both greater self-awareness and self-regulated positive behaviors on the part of leaders and associates, fostering positive selfdevelopment".

The central idea of this definition is the positive psychological capacity. This capacity can be derived from the individual, the work teams, the organization or the community. In this rationale authentic leaders are people with high level of authenticity: they know who they are, what they believe, what they are enjoying, and interacting with others act according to their values and beliefs (Avolio \& Gardner, 2005; Avolio, Gardner, Walumbwa, Luthans, \& May, 2004a).

In fact, the peak of the positive organizational studies in which AL emerges, leads to pay, more and more attention to leadership aspects related to self-fulfillment, both of the leader as of the people working with him. Leaders guide the followers in the right direction, winning their agreement with the organization's mission and then motivate them to achieve the goals defined by leaders and followers together. We can understand the leaders as people who do what is right to do, compared with managers who do what is right to do (Bennis \& Nanus, 1986: p. 21).

It is in this line of thought that is emerging the current of transformational leadership (Bass 1985, 1990), by which leader gets extraordinary effects on followers results. The transformational leader works with his followers in order to generate creative solutions to complex problems, at the same time developing them to handle more responsibilities related to leadership (Bennis, 2001). Transformational leadership requires the leader to convey a powerful and positive outlook, in addition, to meet the individual needs of his followers (Walumbwa et al., 2008).

However, in the development of studies on transformational leadership emerged a paradox: the transformational leader being dishonest. That is, the transformational leader had not, necessarily, to act morally and ethically (Furmanczyk, 2010). As mentioned, people felt betrayed and many organizations have collapsed for lack of integrity of its leaders (Smith, Bhindi, Hansen, Riley, \& Rall, 2008).

Thus, in a context of increasingly complex and demanding on standards of leadership, appeared AL, people-centered and sustained in equity, ethical posture, and orientation to values and compassion.

The words that most associate with AL while construct related to positive psychology are: genuine, reliable, and believable and hope engine. All this contributes to the sense of authenticity is key in these troubled times, when the environment changes, in which the rules, effective earlier, crumble and where leaders cannot avoid being transparent (Cameron et al., 2003).

AL has been built from the contributions of both leaders and followers. In fact, as Kets de Vries (2009) says, leadership is a team sport. For example, Goffee \& Jones $(2000,2006)$, based on the experience gained over ten years of consulting companies in the United States and Europe, introduced the idea that leader could do nothing without followers. 
Goffee and Jones believe that followers are constantly asking "Why should anyone be led by you?" of their leaders. Leaders must use their everyday words and actions to provide their response.

The authors considered that followers want four key things from their leaders:

1) Authenticity

Goffee and Jones believe that authenticity in leadership is extremely important. One of the key things that followers want is for their leaders to show their human side rather than just a management persona. In other words, they want leaders who are extremely good at what they do, but who have not lost sight of where they have come from, or who they are.

2) Significance

Followers tend to respond to leaders who make them feel like their contributions matter, no matter how small. This, Goffee and Jones point out, is tied up with our basic human need to have a purpose and be valued. Those followers who are made to feel significant by their leader tend to respond with loyalty and support.

3) Community

According to Goffee and Jones, followers also look for their leaders to create a sense of community. By this, they mean a feeling of common purpose at work, and a desire within the group to relate and interact with each other. Unfortunately, creating such an environment is extremely difficult. Goffee and Jones believe that few executives ever achieve it.

4) Excitement

While it is acknowledged that different types of people can make effective leaders, Goffee and Jones believe that, in their heart of hearts, what followers want is to get a buzz and feeling of excitement from their leader. Many successful organizations such as Virgin or the Body Shop have had leaders who have an energy and edge that rubs off on their employees. Again, it's human nature to want to feel engaged and to be part of a success story.

And if it is difficult to find followers, the more complicated it is to answer the question: What to do so that followers choose to follow someone?

Following closely Goffee \& Jones (2000, 2006), leaders who inspire followers to follow them, share "four unexpected qualities". First, leaders need to show, selectively, its weaknesses. Expose a weakness shows that one needs the other, which is perfectly normal. Not least because if leaders do not show weaknesses, followers eventually discover quickly some. However, the leader has to be wary of exposing weaknesses, that is you need to have the art on the selective choice of weakness to show why it should not be critical to the activity that develops, for example, the fact that a school principal does not know how to deal with disciplinary problems of students.

The second quality passes through the strong commitment of the leaders on intuition when defining moments and ways to take action. Leaders must trust their instincts. Goffee and Jones call these sensory leaders "good detectors of 
situations". This can cause problems because on the one hand, anticipation of situations may involve conflicts and loss of confidence of followers, and on the other, because a sense can interfere with the natural course of things, which is the truth. Thus, the leader must, in their own interest, validate their feelings using the help of trusted members of his team.

As third quality leaders need to know how to manage their relationship with the followers with strict empathy. There are no relationship recipes with followers. Soon, the empathic relationship leader/followers must be strictly one that followers need to develop their work. In other words, the leader cannot always bring their followers "in his arms". There are times when they have to take risks and then, yes empathy must be strong.

Finally, leaders must clearly show their differences. One way of leaders remain in this condition is to use, clearly, what they have unique. A difference only gives advantage if it is known and accepted by others. And this difference need not be magnificent or overwhelming, just to be subtly effective. It is not enough to be competent at what you do, you must continue to want to do it better and better every day. Without departing from the followers are these differences that leader must communicate them.

All that Goffee \& Jones (2000: p. 8) propose in has to be framed in a challenge, with no receipts, that requires each of the leaders to be more capable, remaining equal to itself. "The four leadership qualities are the first step. All together call on leaders to be authentic."

More recent studies carried out in different parts of the world, from China (Walumbwa et al., 2008) to New Zealand (Caza, Bagozzi, Wooley, Levy, \& Caza, 2010), passing by, as is inevitable, the United States (Walumbwa, Luthans, Avey, \& Oke, 2011), through ALQ (Authentic Leadership Questionnaire), Walumbwa et al. show that there is a positive relationship among $\mathrm{AL}$ and various psychosocial and organizational variables, namely, psychological capital, followers satisfaction at work and with the leader, organizational citizenship behavior, trust, organizational commitment and work performance.

The affirmation of the AL construct, from the perspective of social psychology, flashed through his clarification (Walumbwa et al., 2008: p. 94):

"A pattern of leader behavior that draws upon and promotes both positive psychological capacities and a positive ethical climate, to foster greater selfawareness, an internalized moral perspective, balanced processing of information, and relational transparency on the part of leaders working with followers, fostering positive self-development".

Self-awareness means that leaders know what is important to them (May, Hodges, Chan, \& Avolio, 2003). Sparrowe (2005), representative of the AL philosophical current that focuses on the succession of events contributing to the development of the person (narrative self), relates self-awareness to the self-regulation to the extent that this helps the leader to realize contradictions between what he intrinsically defends and its performance. Whether that are values, identity, emotions, goals or motives, leaders have to know well them- 
selves. This factor allows to evaluate the level of knowledge/awareness that leader has about its strengths and weaknesses, those from the followers and how its actions influence the actions of others (Avolio \& Gardner, 2005: p. 324). It is clearly considerd self-awareness as a dynamic process over time (Walumbwa et al., 2008: p. 95).

The internalized moral perspective is directly related to the self-regulation of the leader's conduct according to personal values and principles, given the pressures of the group, organization or society (Walumbwa et al., 2008: p. 96). This process consists of three steps. At first, the individual evaluates his personal standards. Then he evaluates the differences between those standards and the expected results. Finally, he identifies the actions that decrease such shocks (Avolio \& Gardner, 2005: p. 325). Therefore, the conduct of the leader is consistent with their personal beliefs and values, not intending to please others, receive bonuses or avoid penalties. In short, without being utilitarian/opportunist.

The assumption that the processing of information by the leader, would never run the risk of bias, early by Kernis (2003) and carried out by Ilies et al. (2005), was called into question by the fact that the leader will not be free of this limitation on direct analysis of information. Avolio \& Gardner (2005) and Walumbwa et al. (2008) proposed in its place the balanced information processing (balanced processing), which implies that authentic leaders have the ability to consider objectively, in the analysis of information relevant to decision-making, all the nuances that make it up. And if necessary, they are able to collect other points of view even if they are contrary to them.

Finally, relational transparency combines the authenticity of the leader with the ability that he demonstrated in open to others and to show as he is, the "real you" (Walumbwa et al., 2008: p. 95). In turn, George (2003: p. 12) describes the authentic leadership as "being yourselves". This is an opening generating factor and confidence between the followers and the leader that simplifies the sharing of thoughts and emotions (Gardner et al., 2005).

As it appears from the clarifying definition of AL it is solidly founded on the development, coordination and performance of values, specifically by the leader, and the development of the authentic follower (Walumbwa et al., 2008: p. 93). Given that, there is no leadership without followers, the AL theory adopts the most important positions of LMX theory (Leader Member Exchange-Exchanges between leaders and followers) as it relates to the congruence of values between leaders and followers. The LMX focuses on the leadership process in the two-way of the exchange relationship between leaders (personal and positional features) and its employees (performance). This special relationship is designated by Dansereau, Graen, \& Haga (1975) as the dyadic relationship. More recent studies (Graen \& Uhl-Bien, 1995) aim to relate the LMX theory with organizational effectiveness, process in which the leader should gradually develop high quality exchanges with all its employees instead to do so with only a few. Such a path is developed in three phases: strangeness, acquaintance and mature part- 
nership.

AL, which can be summarized to knowledge and loyalty to himself (May, Hodges, Chan, \& Avolio, 2003), is based on the moral component and the values of its leaders and followers. As Bhindi, Smith, Hansen, \& Riley (2008: p. 3) argue, AL combines two forces that are intertwined. On the one hand, "the transformation of thyself and others to a higher purpose of morals and ethics." Does not depend on hierarchical level, it is conquered by the leader and granted by followers. It is based on the integrity and credibility of the leader. "It is a collective process involving leader and followers. Such leaders "do what they say 'in all aspects of their responsibilities and gain the confidence of others". On the other, it is the "uncompromising respect or a search for a high moral code or ethical standard of conduct".

In turn, Doise (1982) distinguishes four levels of analysis in the explanations drawn up by social psychologists to social phenomena: intra-individual, interindividual, intergroup and societal. Intraindividual explanations are that analyze social phenomena based on the individual's psychological motivations. The interindividual level, the explanations are based on the relationships that occur between an individual and another individual in a given situation. In the intergroup level, it focuses on the dynamics of relationships that social groups have with the other groups, being dependent phenomena of social identification of individuals with these groups (Doise, 1976). At the societal level, explanations are based on the ideologies underlying the way social groups relate (Camino, 1996).

As mentioned in the previous chapter, closely following Schwartz (1992, 1994 and 2001), values express motivations that have a dynamic organization, determined by the nature of targeted interests, which facilitates the anticipation of behavior from the person motivational structure.

\section{Trust}

Covey et al. (2007) identified trust as the number one competence of leadership. It is like a currency, a reputation or brand. The ability to establish, grow, extend and restore trust among all stakeholders is the needed core competency of today leadership. In learning and establishment of a culture of trust, the author advises starting with the construction of the very credibility of each one before using it as a leader, as a team and as an organization. Credibility based on character and competence is the root on which trust is based. To do what we say we do it takes courage. It's easy to do what is right when it implies no costs or sacrifices. It is much more difficult when there is an associated cost. Especially when the concern is focused on employees and/or on team, it values leadership. It's a win-win relationship, a mutual benefit relationship, where all parties win, as opposed to a manager whom employees know that he is only concerned with $\mathrm{him} /$ herself. Another issue that can arise is the relevance of each one to the extent we are always learning and growing. To stay relevant we need to innovate. 
To remain credible leader has to achieve tangible results. So it is the performance history and the internal consistency that build trust.

As for Mayer et al. (1995), there are three crucial leader characteristics building trust: competence, benevolence and integrity. Competence would be related with the knowledge and experience of leading on the type of tasks to be undertaken, benevolence would be the leader belief that his followers would be in good faith and integrity would include the followers' perception associated to the fact that the leader honors what has been agreed.

Avolio et al. also argue that "Authentic leaders build benevolence and integrity with their followers by encouraging totally open communication, engaging their followers, sharing critical information, and sharing their perceptions and feelings about the people with whom they work; the result is a realistic social relationship arising from followers' heightened levels of personal and social identification." That is, when followers believe in the leader's capacity, integrity and benevolence, they become more confident and willing to take risks (Mayer et al., 1995). It's called the propensity to trust.

This all suggests that trust acts as an enhancer of relationships and business. For Covey (2007) there are fees and dividends associated with trust. That is, when trust diminishes, business relationships become slower and this entails increased costs. Otherwise, when trust is increasing, relationships and business are more fluid, soon we will have savings. Trust acts as an engine to relationships and economy. Hence the authentic leader must feed, in organizational culture, the flourishing practices which prevail trust. It will thus be easier to achieve positive attitudes and behaviors on the part of followers.

But Rego et al. (2007) leaves us some advice: "is required "smart trust" and not a "blind", "naive" or "lax" trust. Trust even has reason to distrust. Be wary even when have reason to trust ... avoiding overconfidence, or the lack of trust. It is a risk management". In fact, combine the propensity to trust with a high level of reflection, so that the decision to trust is the result of an intuitive judgment, may be the key attitude in overcoming the current crisis of trust.

Authentic leaders turn out to have a major responsibility in the dissemination of confidence among his followers. "The behavioral style per se is not what necessarily differentiates the authentic from the inauthentic leader" (Avolio et al., 2004a: p. 806), turns out to be manifested as an expression of their values and beliefs, contributing decisively to win the respect and trust of followers.

Covey (2007) identifies thirteen behaviors of high trust leaders: Talk straight, demonstrate respect, create transparency, right wrongs, show loyalty, deliver results, get better, confront reality, clarify expectations, practice accountability, listen first, keep commitments and extend trust. Among them, Covey stands honor commitments like the behavior number one in building trust not forgetting that being trust a mutual behavior there is a responsibility to spread trust to create an organizational culture based on it.

The remaining behaviors identified fall into, generically, in the categories used 
by Wallumbwa, Avolio, Gardner, Wernsing, \& Peterson (2008) in the development of "Authentic Leadership Questionnaire" and the operational definition of authentic leadership construct.

As mentioned, trust contributes to the different forms of exchange, especially in those that are processed at the organizational level. The quality of those exchanges, of what we give, receive and returned to give is fundamental to our self-esteem. Hence, Poirier (2008) proposes us a new way to free the debt of the gift and discover the relational wealth of giving without the partner staying with no debt. It is in the frank and open dialogue, recognition of others and self-esteem, which is the secret of relational transparency.

Trust is more than a social virtue, it is a transformation instrument of the future. If we mix it with the existence of obstacles or crises, rather than consider them as a source of discouragement, we can see them as opportunities to do something new. Authentic leadership here's main function is to spread optimism and positivity.

You cannot fall into that state of torpor that Victor Frankl, an Austrian psychiatrist who was imprisoned in a Nazi death camp and wrote the important book "Man's Search for Meaning," lamented saying, "People have enough to live by, but nothing to live for; they have the means, but no meaning". A meaningful life is, for many, relatively clear and easy to identify and achieve, for example, family life. For others never stood as a problem, because they live totally focused on the means rather than the meaning of life. It is therefore critical to transform the current recessionary challenges into opportunities to understand and add meaning to work and life.

Kouzes \& Posner (2009) to, and consider that "the certainty and routine lead to complacency" Kouzes \& Posner (2009, p. 192), it is essential to note that "Great leaders such as large companies and large countries, create meaning and not just money" Kouzes \& Posner (2009, p. 146). Hence, the authors consider that exist in all extraordinary experiences of leadership, "The Five Practices of Exemplary Leadership":

- Model the Way-looking for opportunities, taking risks;

- Inspire a Shared Vision-envisioning the future, attracting others;

- Challenge the Process-by example, using the errors;

- Enable Others to Act-feeding collaboration, creating trust;

- Encourage the Heart-showing "gratitude for the people contributions" and creating "a culture of celebration of values and victories" (ibid, pp. 36-45).

\section{Learning Organizations}

According to Fernandes, learning organizations "are organizations that have a constant concern to improve its performance and to this end develop the potential of its employees to meet new standards of knowledge that enable them to acquire, transfer and create knowledge". The author, in more recent work, considers organizational learning as "the process by which an organization trans- 
forms information into new knowledge to find better answers to the environment.

Kinicki and Kreitner explain that "organizational learning and learning organization are not the same thing." For them learning it appears as a process of collecting and cognitive and social interpretation of information while apprentice or learning organization uses the knowledge gained to improve the organization performance.

Bouvier considered that the concept of organizational learning refers to organizations that are in a constant process of learning, i.e. the learning organizations or those that are "able to learn". In this perspective learning organization "is an action, driving the action and collective learning system, which learns permanently, and capitalize their knowledge, their ways of doing well and their skills to convey and turn in the voluntarily towards achieving your goals, depending on the evolution of its environment, its resources, culture and representations of stakeholder groups" (o.c., p. 34).

Learning organizations are institutions where people continually expand their capacity to create the results they truly desire, where there are new and high standards of reasoning, where collective aspiration is free and where people continually learn to learn together (Senge, 2006: p. 37).

In fact, "the organizations only learn through individuals who learn" (Senge, 2006: p. 167) but it is also true that people, "the agents" of organizational learning only learn organizationally if "truly" know "the organizational memories; i.e. they have to have coded images, maps of theory-in-use of the organization". That is, the individual's learning is not enough to ensure the entire organizational learning but without a set of coded individual learnings, organizational learning will not exist.

(Senge, 2006: pp. 17-29) based organizational learning in the permanent exercise of five disciplines that allow the absorption of knowledge in organizations, encourage continuous learning of its employees and aimed at the incorporation of new knowledge in the work processes. These principles, according to the author, lead organizations to adopt strategies, procedures and practices permanent evaluation of their performance. This requires that they are aware of their evolutionary process.

Bouvier assumes that "...the learning in the organization, and the organization, you need to save-to convey - the lessons of experience to be a lively and accessible organizational memory". In the view of this author, one of the conditions for an organization or school and be learner is that learning is connected to the evaluation. In other words, organizational learning becomes useful to the organization if comparisons with similar organizations are learning made (benchmarking), is proceeding to the self-evaluation and external evaluation of the organization's action, so that such achievements to establish themselves as "instruments progress" (ibid., p. 42).

But for change happens, most of other actors personally committed to the organization have to be involved. Teacher, in particular, has to act as key support 
in the production of knowledge to add to the organizational knowledge. And it will require a lot of dialogue.

Learning in organizations means also continually test our experience and transform this experience into knowledge, accessible to the whole organization and relevant to the achievement of its objectives.

Senge (1990) put the process of reflection in the center of organizational learning. He suggested that leaders, rather than being individualistic too much, gain to participate in highly collaborative activities with designers, teachers and assistants in organizations as other people who are continuously learning, adapting to changing environments and creating new ways of being.

\section{Conclusion}

A literature review is a very difficult way to make a complete research about so important constructs as leadership, trust or learning organizations. There are not so many elaborated papers on the subject quality of leadership and on this special kind of implicated constructs. We are sure that our study did not empty the theme but we propose this contribution to help colleagues to do better and efficient future researchs.

However, we can conclude that in this context of growing importance of the organizational health, focused on the interaction among people in a learning organization structure, it is important to assume the great role of authentic leadership components on leadership quality.

Personal, cultural and organizational values represent the special glue that unites internally the organizations. Configurating and driving the true mission of each one is contributing to its success and perenniallity. We need so more of this.

We need also more Authentic Leadership in our labor relationships. Leadership which is not felt, absent heart. People want more than command and control, they want most of all significance, self-awareness, ethical and transparent relationships and excitement on the profile of their leaders. Engaging others and enacting values it is the way.

Yes, but how do we build it all without trust? The social glue of relations speed means the difference between the quality and the non-quality of leadership mainly on the organizational level.

Finally, an organization that has a mission and a certain vision need to shift its ways of learning the best practices and continuously incorporate on leadership new insights of feeling part of the whole.

\section{Conflicts of Interest}

The authors declare no conflicts of interest regarding the publication of this paper.

\section{References}

Avolio, B., \& Gardner, W. (2005). Authentic Leadership Development: Getting to the 
Root of Positive Forms of Leadership. The Leadership Quarterly, 16, 315-338. https://doi.org/10.1016/j.leaqua.2005.03.001

Avolio, B., Gardner, W., Walumbwa, F., Luthans, F., \& May, D. (2004a). Unlocking the Mask: A Look at the Process by Which Authentic Leaders Impact Follower Attitudes and Behaviors. The Leadership Quarterly, 15, 801-823.

https://doi.org/10.1016/j.leaqua.2004.09.003

Awolowo, I., Garrow, N., Clark, M., \& Chan, D. (2018). Accounting Scandals: Beyond Corporate Governance. Journal of Modern Accounting and Auditing, 14, 399-407. https://doi.org/10.2139/ssrn.3101057

Bass, B. M. (1985). Leadership and Performance beyond Expectations. New York: The Free Press.

Bass, B. (1990). From Transactional to Transformational Leadership: Learning to Share the Vision. Organisational Dynamics, 18, 19-31. https://doi.org/10.1016/0090-2616(90)90061-S

Bennis, W., \& Nanus, B. (1986). Leaders: The Strategies for Taking Charge. New York: Harper Perennial.

Bennis, W. (2001) Leading in Unnerving Times. MIT Sloan Management Review, 42, 97-103.

Bhindi, N., Smith, R., Hansen, J., \& Riley, D. (2008, April-May). Authentic Leadership in Education: A Cross-Country Reality? Paper Presented at the Enhancing the Heart, Enriching the Mind at the International Leadership Conference, New Zealand 13 Educational Administration and Leadership Society (NZEALS), Auckland, 30 ${ }^{\text {th }}$ April- $3^{\text {rd }}$ May.

Cameron, K., Dutton, J., \& Quinn, R. (2003). Positive Organisational Scholarship: Foundations of a New Discipline. San Francisco, CA: Berrett-Koehler, Inc.

Camino, L. (1996). Uma abordagem psicossociológica no estudo do comportamento político. Psicologia e Sociedade, 8, 16-42.

Caza, A., Bagozzi, R. P., Woolley, L., Levy, L., \& Caza, B. B. (2010). Psychological Capital and Authentic Leadership: Measurement, Gender and Cultural Extension. Asia-Pacific Journal of Business Administration, 2, 53-70. https://doi.org/10.1108/17574321011028972

Cooper, C., Scandura, T., \& Schriesheim, C. (2005). Looking Forward But Learning from Our Past: Potencial Challenges to Developing Authentic Leadership Theory and Authentic Leaders. The Leadership Quarterly, 16, 475-493. https://doi.org/10.1016/j.leaqua.2005.03.008

Covelli, B., \& Mason, I. (2017). Linking Theory to Practice: Authentic Leadership. Academy of Strategic Management Journal, 16, 1-10.

Covey, S. (2004). The 8th Habit: From Effectiveness to Greatness. New York: Free Press.

Covey, S. M. R., Covey, S., \& Merrill, R. (2007). A Velocidade da Confiança: O Elemento Que Faz Toda a Diferença. S. Paulo: Campus/Elsevier.

Dansereau, F., Graen, G., \& Haga, W. J. (1975). A Vertical Dyad Linkage Approach to Leadership in Formal Organizations. Organizational Behavior and Human Performance, 12, 46-78. https://doi.org/10.1016/0030-5073(75)90005-7

Doise, W. (1976). L'articulation psychosociologique et les relations entre groupes. Bruxelas: De Boeck.

Doise, W. (1982). L'explication en psychologie sociale. Paris: PUF.

Furmanczyk, J. (2010). The Cross-Cultural Leadership Aspect. Journal of Intercultural 
Management, 2, 67-82.

Gardner, W., Avolio, B., \& Walumbwa, F. (2005). Authentic Leadership Development: Emergent Themes and Future Directions. Leadership and Management, 3, 387-406.

Gardner, J. (1995). The Cry for Leadership. In J. T. Wren (Ed.), The Leaders' Companion: Insights on Leadership through the Ages (3-7). New York: Free Press.

George, B. (2003). Authentic Leadership: Rediscovering the Secrets to Creating Lasting Value. San Francisco, CA: Jossey Bass.

Goffee, R., \& Jones, G. (2000). Why Should Anyone Be Let by You? Harvard Business Review, 78, 62-70.

Goffee, R., \& Jones, G. (2006). Why Should Anyone Be Let by You? Boston, MA: Harvard Business School Press.

Goffee, R., \& Jones, G. (2006). The Art of Followership. European Business Forum, 25, $22-26$.

Graen, G., \& Uhl-Bien, M. (1995). Development of Leader-Member Exchange Theory of Leadership over 25 Years: Applying a Multilevel Perspective. Leadership Quarterly, 6, 219-247. https://doi.org/10.1016/1048-9843(95)90036-5

Hofstede, G. (1997). Cultures and Organizations: Software of the Mind. New York: McGraw-Hill.

Ilies, R., Morgeson, F. P., \& Nahrgang, J. D. (2005). Authentic Leadership and Eudaemonic Well-Being: Understanding Leader-Follower Outcomes. The Leadership Quarterly, 16, 373-394. https://doi.org/10.1016/j.leaqua.2005.03.002

Kernis, M. H. (2003). Toward a Conceptualization of Optimal Self-Esteem. Psychological Inquiry, 14, 1-26. https://doi.org/10.1207/S15327965PLI1401_01

Kets de Vries, M. (2009). Putting leaders on the couch, available in 23rd July, 2010. https://knowledge.insead.edu/leadership-management/talent-management/putting-lea ders-on-the-couch-1954?vid=12

Kouzes, J. M., \& Posner, B. Z. (2009). O Desafio da Liderança. Casal de Cambra: Caleidoscópio.

Kouzes, \& Posner, B. Z. (2012). The Leadership Challenge. San Francisco, CA: Jossey-Bass, 5th Edition.

Locke, E. A. (1991). The Motivation Sequence, the Motivation Hub and the Motivation Core. Organizational Behavior \& Human Decision Processes, 50, 288-299. https://doi.org/10.1016/0749-5978(91)90023-M

Luthans, F., \& Avolio, B. (2003). Authentic Leadership Development. In K. S. Cameron, S. E. Dutton, \& R. E. Quinn (Eds.), Positive Organizational Scholarship-Foundations of a New Discipline (pp. 241-258). San Francisco, CA: Berrett-Koehler.

May, D. R., Hodges, T. D., Chan, A. Y. L., \& Avolio, B. J. (2003). Developing the Moral Component of Authentic Leadership. Organizational Dynamics, 32, 247-260. https://doi.org/10.1016/S0090-2616(03)00032-9

Mayer, R., Davis, J., \& Schoorman, F. (1995). An Integrative Model of Organization Trust. Academy of Management Review, 20, 709-734. https://doi.org/10.5465/amr.1995.9508080335

Meyer, J., \& Allen, N., (1991). A Three-Component Conceptualization of Organizational Commitment. Human Resources Management Review, 1, 61-89.

https://doi.org/10.1016/1053-4822(91)90011-Z

Poirier, P. (2008). Don et management-De la libre obligation de dialoguer. Paris: L'Harmattan. 
Robbins, S. P. (2007). Comportamento Organizacional (11th ed.). São Paulo: Pearson Prentice Hall.

Rego, A., Souto, S. C., \& Miguel, P. (2007). Espiritualidade nas organizações, positividade e desempenho. Comportameto Organizacional e Gestão, 13, 7-36.

Schwartz, S. (1992). Universals in the Content and Structure of Values: Theoretical Advanced and Empirical Tests in 20 Countries. In M. Zanna (Ed.), Advanced in Experimental Social Psychology (pp. 1-65). Orlando, FL: Academic Press. https://doi.org/10.1016/S0065-2601(08)60281-6

Schwartz, S. (1994). Are There Universal Aspects in the Structure and Contents of Human Values? Journal of Social Issues, 50, 19-45. https://doi.org/10.1111/j.1540-4560.1994.tb01196.x

Schwartz, S. (1999). A Theory of Cultural Values and Some Implications for Work. Applied Psychology: An International Review, 48, 23-47. https://doi.org/10.1111/j.1464-0597.1999.tb00047.x

Schwartz, S. (2001). Value Hierarchies across Cultures: Taking a Similarities Perspective. Journal of Cross-Cultural Psychology, 32, 268-290.

https://doi.org/10.1177/0022022101032003002

Schwartz, S., \& Bilsky, W. (1987). Toward a Universal Psychological Structure of Human Values. Journal of Personality and Social Psychology, 53, 550-562. https://doi.org/10.1037/0022-3514.53.3.550

Senge, P. (2006). The Fifth Discipline: The Art and Practice of the Learning Organization. New York: Doubleday/Currency.

Smith, R., Bhindi, N, Hansen, J., Riley, D., \& Rall, J. (2008). Questioning the Notion of "Authentic" Leadership in Education: The Perspectives of "Followers". In: P. L. Jeffery (Ed.), Changing Climates: Education for Sustainable Futures AARE (1-6). Australian Association for Research in Education.

http://ocs.sfu.ca/aare/index.php/AARE_2008/AARE/paper/viewFile/816/101

Sparrowe, R. (2005). Authentic Leadership and the Narrative Self. The Leadership Quarterly, 16, 419-439. https://doi.org/10.1016/j.leaqua.2005.03.004

Tamayo, A. (1996). Valores organizacionais. In A. Tamayo, J. E. Borges-Andrade, \& W. Codo (Eds.), Trabalho, Organizações e Cultura (pp. 175-193). São Paulo: Cooperativa de Autores Associados.

Tamayo, A., \& Gondim, M. G. C. (1996). Escala de valores organizacionais. Revista de Administração, 31, 62-72.

Tamayo, A., Mendes, A. M., \& Paz, M. G. T. (2000). Inventário de valores organizacionais. Estudos de Psicologia, 5, 289-315.

https://doi.org/10.1590/S1413-294X2000000200002

Tamayo, A. (2005). Impacto dos valores pessoais e organizacionais sobre o comprometimento organizacional. In A. Tamayo, \& J. B. Porto (Eds.), Valores e comportamento nas organizações (pp. 160-186). Rio de Janeiro: Vozes.

Valverde, P. (2000). Máscara, Mato e Morte em São Tomé. Oeiras: Celta Editora.

Walumbwa, F., Avolio, B., Gardner, W., Wernsing, T., \& Peterson, S. (2008). Authentic Leadership: Development and Validation of a Theory-Based Measure. Journal of Management, 34, 89-126. https://doi.org/10.1177/0149206307308913

Walumbwa, F. O., Luthans, F., Avey, J. B., \& Oke, A. (2011). Authentically Leading Groups: The Mediating Role of Collective Psychological Capital and Trust. Journal of Organizational Behavior, 32, 4-24. https://doi.org/10.1002/job.653 